\title{
INFLUENCE OF A COBALT-CHROMIUM METAL FRAMEWORK ON SURFACE ROUGHNESS AND KNOOP HARDNESS OF VISIBLE LIGHT-POLYMERIZED ACRYLIC RESINS
}

\author{
INFLUÊNCIA DE ESTRUTURA METÁLICA DE COBALTO-CROMO NA RUGOSIDADE E DUREZA \\ KNOOP SUPERFICIAIS DE RESINAS ACRÍLICAS POLIMERIZADAS POR LUZ VISÍVEL
}

\begin{abstract}
Joane Augusto de SOUZA JÚNIOR ${ }^{1}$, Renata Cunha Matheus RODRIGUES GARCIA², Juliana Silva MOURA ${ }^{3}$, Altair Antoninha DEL BEL CURY ${ }^{4}$
\end{abstract}

\author{
1- DDS, MSc, PhD, Professor, Department of Dentistry, State University of Ponta Grossa (UEPG), Brazil. \\ 2- DDS, MSc, PhD, Professor, Department of Prosthodontics and Periodontology, Piracicaba Dental School, University of Campinas (UNICAMP), \\ Brazil. \\ 3- DDS, MSc, Graduate Student, Department of Prosthodontics and Periodontology, Piracicaba Dental School, University of Campinas \\ (UNICAMP), Brazil. \\ 4- DDS, MSc, PhD, Professor, Department of Prosthodontics and Periodontology, Piracicaba Dental School, University of Campinas (UNICAMP), \\ Brazil.
}

Corresponding address: Renata Cunha Matheus Rodrigues Garcia - Av. Limeira, 901 - Piracicaba, SP - Cep.: 13414 - 903 (Brazil) Phone: +55 1934125294 - Fax: + 551934125250 - e-mail: regarcia@fop.unicamp.br

Received: November 28, 2005- Modification: April 10, 2006 - Accepted: May 20, 2006

\begin{abstract}
A

lthough visible light-polymerized acrylic resins have been used in removable partial dentures, it is not clear whether the presence of a metal framework could interfere with their polymerization, by possibly reflecting the light and affecting important properties, such as roughness and hardness, which would consequently increase biofilm accumulation. The aim of this study was to compare the roughness and Knoop hardness of a visible light-polymerized acrylic resin and to compare these values to those of water-bath- and microwave-polymerized resins, in the presence of a metal framework. Thirty-six specimens measuring 30.0 x $4.0 \pm 0.5 \mathrm{~mm}$ of a microwave- (Onda Cryl), a visible light- (Triad) and a water-bathpolymerized (Clássico) (control) acrylic resins containing a cobalt-chromium metal bar were prepared. After processing, specimens were ground with 360 to 1000-grit abrasive papers in a polishing machine, followed by polishing with cloths and 1- $\mu \mathrm{m}$ diamond particle suspension. Roughness was evaluated using a profilometer (Surfcorder SE 1700) and Knoop hardness (Kg/mm²) was assayed using a microhardness tester (Shimadzu HMV 2000) at distances of 50, 100, 200, 400 and $800 \mu \mathrm{m}$ from the metal bar. Roughness and Knoop hardness means were submitted to two-way ANOVA and compared by Tukey and Kruskal Wallis tests at a 5\% significance level Statistically significant differences were found ( $<<0.05)$ for roughness and Knoop hardness, with light-polymerized resin presenting the highest values $\left(R a=0.11 \mu \mathrm{m}\right.$ and hardness between $\left.20.2 \mathrm{and} 21.4 \mathrm{Kg} / \mathrm{mm}^{2}\right)$. Knoop values at different distances from the metal bar did not differ statistically ( $>>0.05)$. Within the limitations of this in vitro study, it was concluded that the presence of metal did not influence roughness and hardness values of any of the tested acrylic resins.

Uniterms: Light-polymerized acrylic resin; Surface roughness; Surface hardness.
\end{abstract}

\footnotetext{
RESUMO

$R$

esinas acrílicas polimerizadas por luz visível têm sido indicadas para a confecção de próteses parciais removíveis. Entretanto, não há estudos determinando se a presença de estrutura metálica interfere ou não na polimerização, considerando que essa estrutura pode refletir a luz e afetar propriedades como rugosidade e dureza e, consequentemente, facilitar o acúmulo de biofilme bacteriano. O objetivo deste trabalho foi comparar os valores de rugosidade e dureza Knoop de uma resina polimerizada por luz visível com resinas acrílicas polimerizadas por microondas ou banho de água, na presença de estrutura metálica. Para tanto, trinta e seis espécimes nas dimensões de 30,0 x 4,0 \pm 0,05 mm de resina acrílica polimerizada por microondas (Onda Cryl), luz visível (Triad) e banho de água (Clássico) (controle), contendo barra metálica de cobalto cromo foram preparadas. Após a polimerização, os espécimes foram acabados e polidos com lixas abrasivas de 360 a 1000 de granulação em politriz, seguidas de pasta de diamante e disco de feltro. A rugosidade foi avaliada em perfilômetro mecânico (Surfcorder SE 1700) e a dureza Knoop (Kg/mm²) em microdurômetro (Shimadzu HMV 2000) a 50, 100, 200, 400 e $800 \mu$ m de distância da barra metálica. Os valores de rugosidade e dureza Knoop foram submetidos a ANOVA a dois critérios e comparadas com os testes Tukey e Kruskal Wallis ao nível de significância de 5\%. Diferenças estatisticamente significantes foram encontradas ( $\mathrm{p}<0.05$ ) para rugosidade e dureza Knoop, sendo que a resina polimerizada por luz visível apresentou os maiores valores de rugosidade (Ra $=0,11 \mu \mathrm{m})$ e dureza $\left(20,2\right.$ a $\left.21,4 \mathrm{Kg} / \mathrm{mm}^{2}\right)$. Os valores de dureza Knoop não diferiram estatisticamente entre as distâncias (p>0.05). Dentro das limitações deste estudo in vitro, concluiu-se que a presença de metal não influenciou nos valores de rugosidade e dureza das resinas. Unitermos: Resina acrílica polimerizada por luz visível; Rugosidade superficial; Dureza superficial.
} 


\section{INTRODUCTION}

Although water-bath polymerization is extensively used to process polymethylmethacrylate (PMMA), new resins and processing methods are often proposed to obtain better physical and esthetic properties and simplify the technique ${ }^{1,6,8,11,14}$. Two relatively new polymerization methods are microwaving and visible light polymerization ${ }^{7,9}$.

One of the advantages of microwave and visible light polymerization methods is the shorter processing time they offer in comparison to water bath. In addition, lightpolymerized resins can be processed directly in the mouth using a portable light-curing device, which simplifies the clinical procedures ${ }^{9}$.

While denture base acrylic resins polymerized by microwave irradiation and conventional water bath curing systems are composed of PMMA ${ }^{6,8}$, visible lightpolymerized resins are similar to composites, having an organic instead of an inorganic filler content. The material is composed of a urethane dimethacrylate matrix plus small amounts of microfine silica. The filler consists of acrylic resin beads (PMMA) of varying sizes that become part of an interpenetrating polymer network. Light polymerization occurs by exposure to quartz halogen lamps in the shorter blue 400 to $500 \mathrm{~nm}$ wavelength spectrum of visible light. This exposure results in 5 to 6 -mm-deep polymerization ${ }^{7,9,13}$.

Visible light-polymerized resins were initially proposed for clinical repairs and/or additions in sub-extended removable dentures ${ }^{7}$, but due to their easy manipulation and fast polymerization, their are now indicated for many clinical situations, such as transitional and interim dentures, complete and removable partial dentures, provisional splints, denture repairs and additions, orthodontic appliances and record bases ${ }^{5,7,9}$.

Although light-polymerized resins have been used in removable partial dentures, it is not clear whether the presence of a metal framework could interfere with their polymerization, by possibly reflecting the light and affecting important physical properties, such as surface roughness and hardness. These properties are largely investigated because they indicate polymerization characteristics, $4,11,14$ and might influence plaque accumulation later on ${ }^{2,3,10}$. Thus, the aims of this study were to investigate whether metal interferes with the surface hardness and roughness of a visible light-polymerized acrylic resin and to compare these values to those of water-bath- and microwave-polymerized resins.

\section{MATERIALAND METHODS}

The resins used in this study are listed in Table 1 . Twelve disc-shaped specimens, $30 \mathrm{~mm}$ in diameter and $4 \mathrm{~mm}$ thick, were fabricated for each resin according to the manufacturers' directions. All specimens were made using a silicone (Optosil, Heraeus Kulzer, Hanau, Germany) matrix (30 \pm 0.05 $\mathrm{mm}$ in diameter and $4 \pm 0.05 \mathrm{~mm}$ thick). The matrix was flasked in Type III dental stone (Herodent Soli-Rock; Vigodent, Rio de Janeiro, RJ, , Brazil) using standard metal dental flasks (Uraby; DLC, São Paulo, SP, Brazil) or plastic flasks (Onda Cryl; Artigo Odontológicos Clássico Ltd, São Paulo, SP, Brazil) for water bath and microwave polymerization, respectively. After the gypsum had completely set, the flasks were opened and the matrixes were removed. A separating medium (Al-Cote, Dentsply Ltd, Rio de Janeiro Brazil) was applied to the exposed areas of the mold. Before packing the resin, a rectangular ( $28 \mathrm{~mm} \times 8 \mathrm{~mm} \times 0.5 \mathrm{~mm}$ ) insert of CoCr alloy bar (Degussa, Hanau, Germany) was centered at the bottom of each mold. As the size of the metal bars was almost the same as that of the mold cavities, once positioned at the bottom of each mold, there was no possibility of metal bar displacement (Figure 1).

Microwave acrylic resin specimens were polymerized in a microwave oven (Continental AW-42, with 2,450 Hz frequency and 900W maximum potency; Bosch, Manaus, AM, Brazil), according to the manufacturer's directions (3 $\mathrm{min}$ at $360 \mathrm{~W} ; 4 \mathrm{~min}$ resting and $3 \mathrm{~min}$ at $810 \mathrm{~W}$ ). Specimens polymerized by hot water bath were processed in an automatic polymerization unit (Termotron P-100; Termotron, Piracicaba, SP, Brazil) at $74^{\circ} \mathrm{C}$ for $9 \mathrm{~h}$. Once processed, all flasks were allowed to bench cooling for $2 \mathrm{~h}$. The resin samples were ground with water-cooled 320-, 400-, 600- and 1200-grit silicon carbide papers (Carbimet; Buehler, Lake Bluff, IL, USA) in a polishing machine (Arotec APL-4; São Paulo, SP, Brazil) followed by polishing with cloths and 1$\mu \mathrm{m}$ diamond suspension (Metadi diamond suspension; Buehler). Next, they were ultra-sound cleaned (ThorntonInpec Eletrônica LTDA, Vinhedo, SP, Brazil) for 2 min and

TABLE 1- Composition, processing method, and manufacturer of acrylic resins

$\begin{array}{llll}\text { Acrylic resin } & \text { Composition } & \text { Processing method } & \text { Manufacturer }\end{array}$

\begin{tabular}{|c|c|c|c|}
\hline Onda Cryl & $\begin{array}{l}\text { Liquid: methylmethacrylate monomer; } \\
\text { Powder: polymethylmethacrylate }\end{array}$ & Microwave & $\begin{array}{l}\text { Clássico Artigos Odontológicos Ltd, } \\
\text { São Paulo, Brazil }\end{array}$ \\
\hline Triad & $\begin{array}{l}\text { Matrix: urethane dimethacrylate } \\
\text { silica; Photoinitiator: camphoroquinone; } \\
\text { Filler: polymethylmethacrylate }\end{array}$ & Visible light & $\begin{array}{l}\text { Dentstply International and } \\
\text { Corporation, York, U.K. }\end{array}$ \\
\hline Clássico & $\begin{array}{l}\text { Liquid: methylmethacrylate monomer; } \\
\text { Powder: polymethylmethacrylate }\end{array}$ & Water bath & $\begin{array}{l}\text { Clássico Artigos Odontológicos Ltd, } \\
\text { São Paulo, Brazil }\end{array}$ \\
\hline
\end{tabular}


then immersed in distilled water at $37^{\circ} \mathrm{C}$ for $12 \mathrm{~h}$ to release residual monomers ${ }^{6,12,14}$.

Light-polymerized resin specimens were prepared using a transparent matrix, consisting of an acrylic resin plate containing a circular hole measuring $30 \pm 0.05 \mathrm{~mm}$ in diameter and $4 \pm 0.05 \mathrm{~mm}$ thick. First, a Co-Cr framework was placed at the bottom of the matrix and then the light-polymerized resin was inserted in the matrix. This assembly was put into a light box (EDG Lux; EDG Equipamentos e Controles, São Paulo, SP, Brazil) containing four $75 \mathrm{~W}$ halogen lamps. The resin was polymerized for 6 min, according to manufacturer's instructions. After processing, the same finishing, polishing and cleaning procedures used for heat and microwave polymerized acrylic resins were carried out.

Surface roughness was determined using a mechanical profilometer with a 2 - $\mu \mathrm{m}$ radius tip under a measuring force of $0.7 \mathrm{mN}$ and accurate to $0.01 \mu \mathrm{m}$ (Surfcorder SE 1700, Kosaka, Tokyo, Japan) calibrated at sample length of 0.25 $\mathrm{mm}$, spread of $2.0 \mathrm{~mm}$ and speed of $0.5 \mathrm{mms}^{-1}$. Six readings were performed on each specimen and an average $\left(R_{a}\right)$ was determined. These profilometric traces were taken from the edge of specimen, in the middle and at its bottom. ${ }^{12}$

Knoop hardness was assessed using a microhardness tester (Shimadzu HMV-2000, Shimadzu Corporation, Kyoto, Japan). Settings for load and penetration were $25 \mathrm{~g}$ and 10 $\mathrm{S}^{12}$. Knoop penetrations were made on the acrylic surface of each sample at distances of 50, 100, 200, 400 and $800 \mu \mathrm{m}$ from the Co-Cr metal bar (Figure 2). Five measurements were performed for each distance and a mean value was calculated.

Roughness means were submitted to two-way ANOVA and compared by Tukey test. Knoop hardness means were

TABLE 2- Surface roughness means $(\mu \mathrm{m})( \pm S D)$ of the acrylic resins

\begin{tabular}{ll}
\hline Acrylic Resin & Means \pm SD \\
\hline Onda Cryl & $0.06 \pm 0.01 \mathrm{~A}$ \\
Triad & $0.11 \pm 0.02 \mathrm{~B}$ \\
Clássico & $0.06 \pm 0.01 \mathrm{~A}$ \\
\hline
\end{tabular}

Mean followed by different letters are statistically different $(p<0.05)$. analyzed by two-way ANOVA with 2 factors: acrylic resins and distances. The acrylic resin groups were compared using Tukey test and distances were compared by Kruskal-Wallis test. The significance level for all variables was fixed at $5 \%$.

\section{RESULTS}

Means and standard deviations for acrylic resin surface roughness $(\mu \mathrm{m})$ are presented in Table 2 . The visible lightpolymerized resin (Triad) showed the highest means $(\mathrm{p}<0.05)$, but the metal alloy did not interfere with surface roughness.

Means and standard deviations for Knoop hardness $\left(\mathrm{Kg} / \mathrm{mm}^{2}\right)$ of acrylic resins at several distances from the metal are described in Table 3. Comparisons between acrylic resins showed that the visible light-polymerized resin (Triad) exhibited significantly higher means $(\mathrm{p}<0.05)$. However, no differences in hardness values at several distances from the metal alloy were found.

\section{DISCUSSION}

Visible light polymerization is an alternative technique for acrylic resin processing. This technique is considered to be time-saving as it does not require cast inclusion, is non-toxic and biocompatible. It is therefore indicated for using in many clinical situations, such as complete and removable partial dentures ${ }^{9}$. However, little is known about the influence of metal alloys on the polymerization process and on important physical properties, such as hardness and roughness. In this study, a visible light-polymerized resin was compared to microwave- and heat-polymerized acrylic resins, which have similar composition and surface characteristics $^{6,8}$.

Smooth surfaces do not readily retain food debris, epithelial cells and bacteria, thus facilitating oral hygiene, reducing the risk of plaque formation and preventing negative effects on periodontal tissues ${ }^{3}$. Therefore, the roughness of intraoral surfaces helps determining their colonization by different microorganisms because retention preferably occurs on rough surfaces, as they provide protection against shear forces ${ }^{2}$.

Acrylic resin roughness is dependent on the polishing

TABLE 3- Koop hardness $\left(\mathrm{Kg} / \mathrm{mm}^{2}\right)$ means $( \pm \mathrm{SD})$ of the acrylic resins at different distances from the metal alloy

\begin{tabular}{lccccc} 
Acrylic resin & \multicolumn{5}{c}{ Distance $(\mu \mathrm{m})$ from metal } \\
& $\mathbf{5 0}$ & $\mathbf{1 0 0}$ & $\mathbf{2 0 0}$ & $\mathbf{4 0 0}$ & $\mathbf{8 0 0}$ \\
\hline Onda Cryl & $16.8 \pm 1.8 \mathrm{aA}$ & $17.2 \pm 2.6 \mathrm{aA}$ & $17.3 \pm 2.3 \mathrm{aA}$ & $17.9 \pm 1.6 \mathrm{aA}$ & $18.0 \pm 1.7 \mathrm{aA}$ \\
Triad & $20.2 \pm 1.2 \mathrm{bA}$ & $21.0 \pm 1.1 \mathrm{bA}$ & $20.9 \pm 1.2 \mathrm{bA}$ & $21.0 \pm 1.1 \mathrm{bA}$ & $21.4 \pm 1.1 \mathrm{bA}$ \\
Clássico & $17.1 \pm 1.8 \mathrm{aA}$ & $17.1 \pm 1.1 \mathrm{aA}$ & $17.2 \pm 0.9 \mathrm{aA}$ & $17.8 \pm 1.0 \mathrm{aA}$ & $18.1 \pm 0.8 \mathrm{aA}$ \\
\hline
\end{tabular}

Mean followed by different letters are statistically different $(p<0.05)$

Lowercase letters indicate differences between acrylic resins and uppercase letters indicate differences between distances from metal. 
method used ${ }^{2}$. In this study, polishing was done with 360-, 400-, 600- and 1000-grit abrasive papers, resulting in roughness values below $0.2 \mu \mathrm{m}$, which is considered clinically acceptable for preventing plaque accumulation ${ }^{2}$. Although the same polishing procedure was carried out for all resins, higher roughness means were found in the lightpolymerized resin group $(0.11 \pm 0.02 \mu \mathrm{m})$. This result may be explained by the large amounts of inorganic compounds in this resin, which were probably exposed during polishing procedures, causing irregularities on the resin surface.

The surface roughness means of microwave-(Onda-Cryl) and water-bath-polymerized (Clássico) resins did not differ statistically ( $\mathrm{p}>0.05)$, probably because of the similarity of their composition. These results are in agreement with those of Rodrigues Garcia et al. ${ }^{12}$ (2004), who investigated the influence of denture cleansers on the surface roughness of heat- and microwave-polymerized resins. However, the findings of the present are in contrast with those of Ulusoy et al. ${ }^{15}$, who reported higher roughness means $(0.31 \mu \mathrm{m})$. It is likely that these differences can be due to the polishing method used in each study because Ulusoy et al. ${ }^{15}$ polished the specimens on a bench lathe using a roller brush with pumice/water paste, followed by a wet polishing wheel and

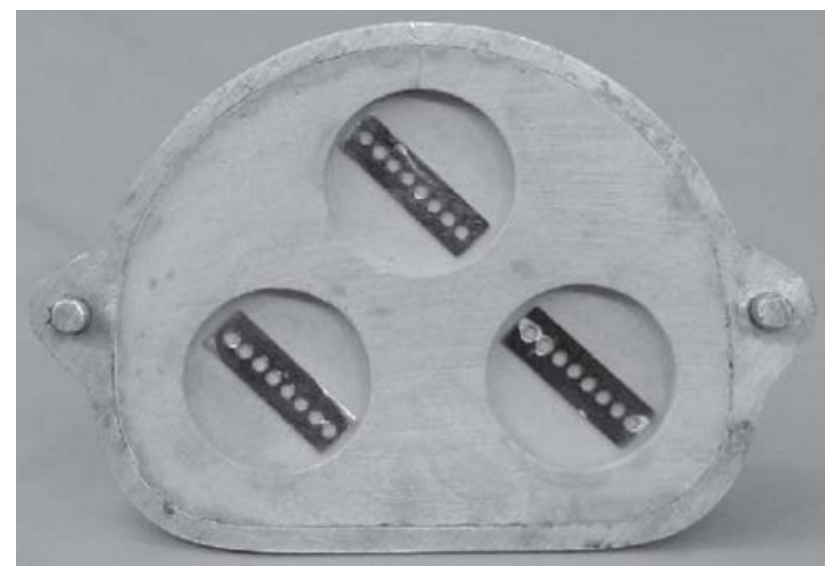

FIGURE 1- Position of Co-Cr metal bars in the mold cavities

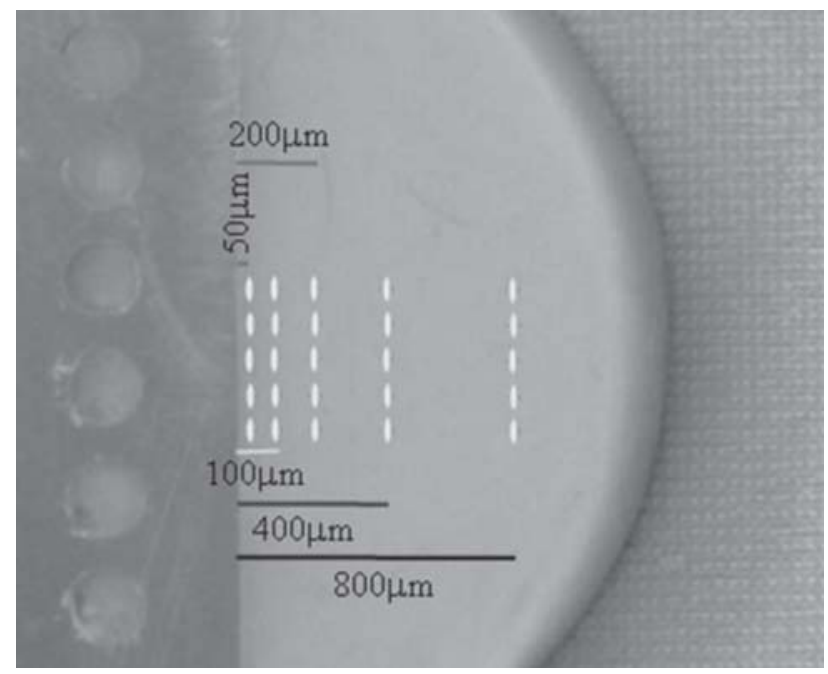

FIGURE 2- Locations of Knoop penetrations from the CoCr metal framework a chalk. In contrast, in the present study, the specimens were polished with materials of decreasing granulation,(up to 1- $\mu$ m diamond particles). The other two resins (Onda Cryl and Clássico), which do not have inorganic compounds, had lower roughness..

Hardness is a property used to predict the wear resistance of a material and its ability to abrade opposing dental structures ${ }^{1}$. Therefore, surface scratching can be determined by its Knoop hardness because its weakness explains why the surface is at risk of roughening during professional cleaning or even during habitual oral hygiene procedures ${ }^{10}$. This test can also be used to verify the efficacy of polymerization. In this study, it was used to assess resin polymerization around a metal alloy.

The visible light-polymerized resin presented the highest Knoop hardness, which is in accordance with Khan et al. ${ }^{7}$ (1987), who compared Triad (Dentsply Inc.) hardness with that of a water-bath-polymerized resin. These results indicated that the visible light-polymerized resin was stronger ${ }^{7}$. This could be explained by the inorganic content of the light-polymerized resin (silica) ${ }^{9}$, which increased the resistance of this resin to the microhardness indenter ${ }^{1}$. Waterbath-and microwave-polymerized resins had similar Knoop hardness means, which are in agreement with many authors ${ }^{4,11,12,14}$.

No differences between 50, 100, 200, 400 and $800 \mu \mathrm{m}$ distances from the metal were found in any of the acrylic resins evaluated $(\mathrm{p}>0.05)$. The absence of significant differences suggests that light emission and polymerization processes were not affected by the presence of metal. These results are in consistent with those of Braun et al. ${ }^{4}$ (1998), who compared water-bath- and microwave-polymerized resins with respect to the hardness means at pre-determined distances from a metal alloy.

In this study, roughness and Knoop hardness results indicated that Triad has clinically acceptable properties and its polymerization was not affected by the presence of metal. However, further studies about the clinical behavior of visible light-polymerized acrylic resins should be conducted.

\section{CONCLUSIONS}

Within the limitations of this in vitro study, it may be concluded that the presence of a metal framework did not interfere with the roughness and Knoop hardness of the tested visible light-polymerized (Triad), microwavepolymerized (Onda Cryl) and water-bath-polymerized (Clássico) acrylic resins, indicating that all materials can be used in removable partial dentures.

\section{REFERENCES}

1- Anusavice, KJ. Philip's science of dental materials. $11^{\text {th }}$ ed. 11 St. Louis: Elsevier Science; 2003.p. 96. 
2- Bollen CML, Lambrechts P, Quirynen M. Comparison of surface roughness of oral hard materials to the threshold surface roughness for bacterial plaque retention: a review of the literature. Dent Mater. 1997;13(4):258-69.

3- Borchers L, Tavassol F, Tschernitschek H. Surface quality achieved by polishing and by varnishing of temporary crown and fixed partial denture resins. J Prosthet Dent. 1999;82(5):550-6.

4- Braun KO, Del Bel Cury AA, Cury JA. Use of microwave energy for processing acrylic resin near metal. Braz Oral Res. 1998;12(2): 173-80.

5- Curtis DA, Eggleston TL, Marshall SJ, Watanabe LG. Shear bond strength of visible-light-cured resin relative to heat-cured resin. Dental Mater. 1989;5(7):314-8.

6- de Clerck JP. Microwave polymerization of acrylic resins used in dental prosthesis. J Prosthet Dent. 1987;57(5):650-8.

7- Khan Z, von Fraunhofer JA, Razavi R. The staining characteristics, transverse strength, and microhardness of a visible light-cured denture base material. J Prosthet Dent. 1987;57(3):384-6.

8- Levin B, Sanders JL, Reitz PV. The use of microwave energy for processing acrylic resins. J Prosthet Dent. 1989;61(3):381-3.

9- Ogle RE, Sorensen SE, Lewis EA. A new visible light-cured resin system applied to removable prosthodontics. J Prosthet Dent. 1986; 56(4):497-506

10- Quirynen M, Bollen CML, Willems G, van Steenberghe D. Comparison of surface characteristics of six commercially pure titanium abutments. JOMI 1994;9(1):71-6.

11- Reitz PV, Sanders JL, Levin B. The curing of denture acrylic resins by microwave energy. Physical properties. Quintessence Int. 1985;6(8):547-51.

12- Rodrigues Garcia RCM, Souza Jr JA, Rached RN, Del Bel Cury AA. Effect of denture cleansers on the surface roughness and hardness of a microwave-cured acrylic resin and dental alloys. J Prosthodont. 2004;13(3):1-6.

13- Rueggeberg FA, Goughman WF, Curtis Jr JW. Effect of light intensity and exposure duration on cure of resin composite. Oper Dent. 1994;19(1):26-32.

14- Truong VT, Thomasz FG. Comparison of denture acrylic resins cured by boiling water and microwave energy. Aust Dent J. 1988;33(3): 201-4.

15- Ulusoy M, Ulusoy N, Aydin AK. An evaluation of polishing technique on surface roughness of acrylic rsins. J Prosthetic Dent. 1986;56(1):107-12. 